\title{
Fruit size and yield efficiency of 'Gala' apples grown in Chile depend on winter temperatures and season length
}

\author{
G. Reginato ${ }^{1}, \mathrm{~K}_{\text {Mesa }}{ }^{2}$ and C. Riquelme ${ }^{1}$ \\ ${ }^{1}$ Universidad de Chile, Facultad de Ciencias Agronómicas, Santiago, Chile \\ ${ }^{2}$ Instituto de Ciencias Agronómicas y Veterinarias, Universidad de O’Higgins, Rancagua, Chile
}

\section{Summary}

The influences of several management practices, as pruning, girdling, chemical and manual thinning on apple fruit size and yield efficiency, are known. Basically, yield improvement is achieved by a successful management of source-sink relationships. However, scarce information is available today about the behavior of environmental factors. A research work was conducted on 'Gala' apples at different locations in central Chile (between 34 and $38^{\circ} \mathrm{S}$ ) among the years 2012-2016, with the objective to associate the differences detected on yield performance with the growing conditions expressed as the temperature regime during the time elapsed between autumn and flowering. For that, the mean, maximum, and minimum temperatures were used to describe weather during the autumns, winters, and early springs, for to be related with yield performance.

Crop load-adjusted yield efficiency ranged between 10.1 and $6.8 \mathrm{~kg} \mathrm{~m}^{-2} P A R_{\mathrm{i}}$, and fruit weight was found to be $134.4 \mathrm{~g}$ and $189.5 \mathrm{~g}$ among zones. The results showed that the crop load-adjusted yield and fruit size depended primarily on the maximum temperature during winter, and secondly, on season length (from bloom to harvest), with colder areas yielding better performance.

Keywords

crop load-adjusted fruit size, crop load-adjusted yield efficiency, $P A R$, intercepted $P A R$

\section{Introduction}

One of the most important quality features for marketing apple is fruit size. This is especially true in cultivars of the 'Gala' group, considered a small apple. It is well known that in order to achieve high quality and optimum fruit size for the market, thinning is the most effective management practice for most deciduous trees. In the fruit trees, yield efficiency and productivity are directly correlated to the amount of carbohydrates synthesized and how these are distributed among vegetative and reproductive organs (Oliveira and Priestley, 1988).

Reginato et al. (2015), after three growing seasons of chemical thinning experiments with 'Gala' type cultivars in the most important Chilean apple growing areas, found differences in fruit size and yield efficiency after adjusting for crop load, expressed as fruit per photosynthetically active radiation intercepted by the trees (fruits $P A R_{\mathrm{i}}^{-1}$ ). With respect to this finding, earlier, Warrington et al. (1999) in-

\section{Significance of this study}

What is already known on this subject?

- Fruit size depends on orchard practices such as pruning and fruit thinning, as well as growing conditions - mainly temperature - after flowering.

What are the new findings?

- Performance of 'Gala' orchards, expressed as fruit size and yield efficiency, is firstly related to winter weather, and secondly to season length.

What is the expected impact on horticulture?

- Apple growing areas must be chosen only after analyzing climatic patterns, especially average maximum winter temperatures.

dicated that the crop load and the genetic, biological carrying capacity (i.e., the source-sink relationships) determine the potential for fruit size development in apple. They also found a strong inverse relationship between the temperature and the growth rate during the cell division phase, although smaller differences in fruit size at harvest were found than would have been expected from the expansion rates under cool conditions.

Several studies have shown a strong positive correlation between temperatures immediately following the bloom in the field and the fruit size at harvest (Beattie and Folley, 1977; Jackson and Hamer, 1980; Lakso et al., 1995). This could explain due to an early exponential cell division phase that is considerably more responsive to temperature than the following cell expansion phase (Warrington et al., 1999).

Additionally, the time when fruit reach harvest maturity may also be influenced by different factors, including bloom date and temperature, that prevail during fruit development, indicating a relationship between accumulated heat units during the first 40 days following petal fall and the time interval between bloom and harvest (Warrington et al., 1999).

In relation to tree performance and the effect of temperature before bloom, Beattie and Folley (1977), Abbot (1971), Jackson et al. (1983), and Jackson and Hamer (1980), found adverse outcomes from higher pre-bloom temperatures (February, March, and April) on the fruit set, which may have affected flower quality and fertility. According to Abbot (1971), the temperature regime from the period of dormant to green cluster appeared to be as important as the period from green cluster to petal fall, as the higher temperatures in the second period are generally beneficial. With his experiment, Abbot (1971) demonstrated the desirability of maintaining a low temperature beyond the bud break period, and 
then the benefit of a rising temperature by the green cluster stage.

Similar results were found by Rodrigo and Herrero (2002) in apricot (Prunus armeniaca L.), where the prebloom temperature also affected the fruit set, as indicated when they increased the maximum temperature by $6-7^{\circ} \mathrm{C}$. Additionally, the flowers that have developed in warmer conditions weighed less and showed less pistil development than the control flowers, caused by a lack of synchrony between the external floral and pistil development, resulting in underdeveloped pistils with a reduced capability to set fruit. A similar reason could explain the difference in flower size that Francescatto (2014) found when comparing 'Gala' apple flowers in Ohio and Brazil.

Following these prior investigations, and since the results obtained by Reginato et al. (2015), our work focused on the differences detected related to crop load-adjusted fruit size and yield efficiency of 'Gala' type apples, with the growing conditions expressed as the temperature regime during the time elapsed between autumn and flowering.

\section{Materials and methods}

\section{Plant material and sampling}

Thirteen trials were established in orchards located in different apple growing areas in Chile for four growing seasons 2012-2016 (Table 1). The orchards were located between $34^{\circ} 20^{\prime} \mathrm{S}$ and $37^{\circ} 40^{\prime} \mathrm{S}$ latitude. The planting density ranged from 1,667 to 2,500 trees ha-1. For each experiment (orchard in each season), homogeneous trees in size were chosen during pre-bloom within each orchard on the basis of trunk cross-sectional area (TCSA, $\mathrm{cm}^{2}$ ). Additionally, the trees were selected for flower density homogeneity. For this, two main branches were established as a sampling unit, at an average height and representative of the evaluated tree.

The orchards were managed following standard cultural practices (i.e., chemical and manual thinning, fertigation, disease and pest control). For the chemical thinning, all spraying was done with a gasoline mist blower backpack (Solo, Germany) with an equivalent water volume of 1,500 $\mathrm{L} \mathrm{ha}^{-1}$. The spraying was performed from the time of bloom until the fruit reached a diameter of $24 \mathrm{~mm}$

\section{Evaluations}

The fruit clusters were counted on two branches of each plant during flowering. Then, the fruits were counted again on the same branches 50 days after full bloom (DAFB), when the natural fruit drop ended. After that, with the aim to remove the effect of the crop load on yield efficiency and fruit size (crop load-adjusted fruit size and yield efficiency) (Reginato et al., 2007), half of the trees of each orchard were hand thinned to a crop load lower than that normally used in each order; the other half was thinned to a level higher than nor- mal. The final crop load was determined at harvest and was expressed as harvested fruit $\mathrm{m}^{-2}$ of intercepted PAR $\left(\mathrm{PAR}_{\mathrm{i}}\right)$ (Reginato et al., 2007).

The $\mathrm{PAR}_{\mathrm{i}}$ of each tree was measured prior to harvest with a line quantum probe (AccuPAR; Decagon Devices, Pullman, WA, USA) using 80 sensors, $1 \mathrm{~cm}$ apart. The AccuPAR model LP-80 is used to measure light interception in plant canopies, and to calculate Leaf Area Index (LAI). The photosensors measure PAR (Photosynthetically Active Radiation) in the 400 to $700 \mathrm{~nm}$ waveband. The AccuPAR displays PAR in units of micromols per meter squared per second $(\mu \mathrm{mol}$ $\mathrm{m}^{-2} \mathrm{~s}^{-1}$ ). Measurements were made three times per day: $2 \mathrm{~h}$ prior to solar noon, at solar noon, and $4 \mathrm{~h}$ after solar noon. The row orientation was North-South, and the radiation interception was assumed to be symmetrical in the morning and afternoon. Incident PAR $\left(\mathrm{PAR}_{0}\right)$ was measured every 20 min outside the orchard, to relate to values of PAR not intercepted $\left(\mathrm{PAR}_{\mathrm{ni}}\right)$. The $\mathrm{PAR}_{\mathrm{ni}}$ was obtained at ground level from five transects (middle row-to-middle row) per tree, with one transect passing by the trunk.

The harvesting was done in two or three picks, and the harvest index was determined according to the background color of the fruit. At the time of harvest, the background color used for selection corresponded to a light yellow. For each harvest, all fruit per tree were counted and weighed to determine the total yield and average fruit size. Yield efficiency was calculated in relation to $\mathrm{PAR}_{\mathrm{i}}$ as $\mathrm{kg} \mathrm{m}^{-2} \mathrm{PAR}_{\mathrm{i}}$.

For each case (location/season), the weather records of minimum and maximum daily temperatures were obtained for each orchard from an automatic weather station located in or close to each field under trial. The mean temperature was calculated by adding the maximum and minimum temperatures and then dividing by two. Average temperatures for periods of time before bloom were classified as autumn, winter, and early and late pre-bloom. Autumn was considered April and May, corresponding to the period before the trees started losing their leaves until complete natural leaf fall. Late pre-bloom corresponded to the period of 100-degree days (base $4.0^{\circ} \mathrm{C}$ ) immediately before bloom, and early pre-bloom corresponded to the period of 100-degree days before late pre-bloom. The period from June to early prebloom was considered winter, when the trees were dormant. To take into account the growing conditions after bloom, the time that elapsed between the bloom and the commercial harvest was included as a variable.

\section{Data analysis}

To standardize fruit size and yield efficiency for each case (location and year), all the trees that had a crop load of between 30 and 80 fruit $\mathrm{m}^{-2}$ of $\mathrm{PAR}_{\mathrm{i}}$ were selected; those outside of this range were not used for the analysis. Thus, for each case, a variable number of trees were considered, ranging from 14 to 146 per case. In order to isolate the effect of crop

TABLE 1. Characteristics of the orchards (locations/season) used in this research work.

\begin{tabular}{lcccc}
\hline Location & Season & Rootstock & Cultivar & $\begin{array}{c}\text { Planting density } \\
(\text { trees ha-1 })\end{array}$ \\
\hline Quinta de Tilcoco & $2012 / 13 / 14 / 15$ & Pajam 2 & Brookfield Gala & 2,192 \\
Chimbarongo & 2015 & M9 & Gala Premium & 2,288 \\
Peor es nada & 2012 & M9 & Brookfield Gala & 2,083 \\
Los Niches & $2013 / 14$ & M9 & Brookfield Gala & 1,667 \\
Yerbas Buenas & 2014 & M9 & Brookfield Gala & 2,500 \\
Angol & $2012 / 13 / 14 / 15$ & M9 & Brookfield Gala & $34^{\circ} 50^{\prime}$ \\
\hline
\end{tabular}


load on fruit size and yield efficiency, we conducted analyses of the covariance, and the adjusted means for each case were considered that corresponded to the crop load-adjusted fruit size and the crop load-adjusted yield efficiency. Data exploration was carried out by principal component analysis (PCA), and fruit size and yield efficiency were described as the function of selected variables by multiple linear regression analysis using the stepwise procedure. In addition, we built regression trees to classify according thresholds. For all analyses, we used the statistical software InfoStat version 2014 (Universidad Nacional de Córdoba, Argentina).

\section{Results}

The average of maximum and minimum temperatures during the autumns, winters and early and late springs for the different seasons (from 2012 and 2015) and locations are shown in Table 2. The average of maximum temperature ranged from 17.0 to $21.4^{\circ} \mathrm{C}$ in autumn, and from 12.0 to $14.6^{\circ} \mathrm{C}$ in winter, respectively, yielding a variation coefficient (VC) close to $7 \%$. In the case of the minimum temperature, more variability was observed in autumn and winter. The averages were between 4.2 to $7.0^{\circ} \mathrm{C}$ and between 3.3 and $5.5^{\circ} \mathrm{C}$, respectively, showing a VC of 15.9 and $17.3 \%$, respectively.

During early pre-bloom, the average maximum temperatures ranged from 15.9 to $19.3^{\circ} \mathrm{C}$. For late pre-bloom, the average maximum temperatures ranged from 16.4 to $24.7^{\circ} \mathrm{C}$. The minimum temperatures during the early and late pre-bloom periods showed the highest variation, with a VC of 36.5 and $29.7 \%$, respectively, meaning a range from 1.7 to $10.3^{\circ} \mathrm{C}$ for early pre-bloom, and between 2.4 and $9.3^{\circ} \mathrm{C}$ for late pre-bloom. According to Warrington et al. (1999), the growing conditions after bloom determines the season length, mainly related to temperature during the initial period of fruit growth, and in our study, the season length varied from 122 to 146 days. This yielded the least variation among the cases, with a VC $5.5 \%$.

In this work, the fruit size and yield efficiency showed a linear response to crop load expressed as fruit per intercepted PAR $\left(\mathrm{m}^{2}\right)$ (30-80 fruit $\left.\mathrm{m}^{-2} \mathrm{PAR}_{\mathrm{i}}\right)$ ) in each case (location/ season) (Figure 1A, B). In fact, after removing the crop load effect and calculating the crop load-adjusted yield efficiency and fruit size, we found almost no significant differences between the chemical thinning treatments within the different cases (data not presented); here, it is important to remem-
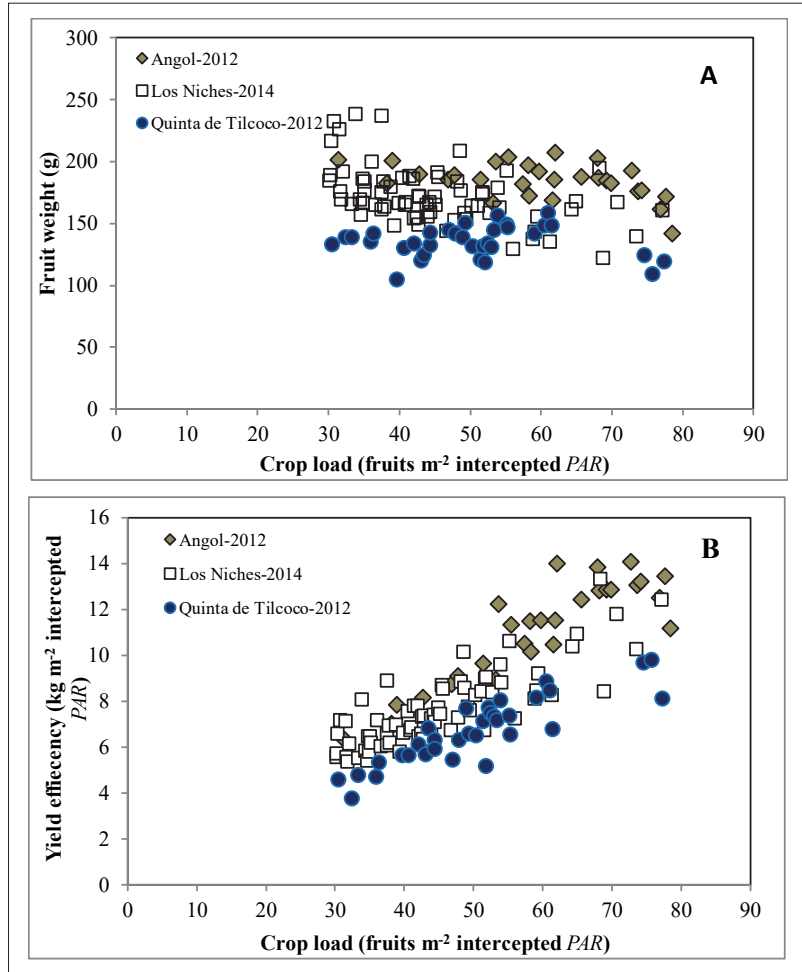

FIGURE 1. Fruit weight (A) $\left(\mathrm{g}_{\text {fruit }}{ }^{-1}\right.$ ) and yield efficiency (B) ( $\mathrm{kg} \mathrm{m}^{-2}$ intercepted PAR) of 'Gala' apple as a function of crop load, expressed as fruit $\mathrm{m}^{-2}$ of intercepted PAR, for three cases (location/season) under trials: Angol, 2012 ( $\diamond$ ), Los Niches, $2014(\square)$, and Quinta de Tilcoco, 2012 (•). Trees for each location/season $(n)=28,72$, and 33, respectively.

ber that hand thinning was performed after the chemical thinning, immediately after the June drop, in order to adjust the final crop load. However, we found a clear differentiation among the cases, showing a similar slope as the response to the increasing crop load (Figure 1A, B).

When the fruit size and yield efficiency were adjusted by crop load by the analysis of covariance, the fruit size from different cases ranged between 134 and $190 \mathrm{~g}$, while yield efficiency measured between 6.9 and $10.1 \mathrm{~kg} \mathrm{~m}^{-2} P A R_{\mathrm{i}}$ (Figure 2 ). These measurements indicate that there was a $40-46 \%$

TABLE 2. Average maximum and minimum temperatures $\left({ }^{\circ} \mathrm{C}\right)$ during autumn, winter, and early and late pre-bloom for different cases under study (location and season).

\begin{tabular}{lccccccccc}
\hline \multirow{2}{*}{ Location } & \multirow{2}{*}{ Year } & \multicolumn{2}{c}{ Autumn } & \multicolumn{2}{c}{ Winter } & \multicolumn{2}{c}{ Early pre-bloom } & \multicolumn{2}{c}{ Late pre-bloom } \\
\cline { 3 - 9 } & & T Max & T Min & T Max & T Min & T Max & T Min & T Max & T Min \\
\hline Quinta de Tilcoco & 2012 & 20.3 & 6.7 & 14.5 & 3.5 & 19.3 & 6.8 & 18.4 & 5.8 \\
& 2013 & 19.0 & 5.0 & 14.6 & 3.3 & 18.2 & 9.5 & 17.4 & 2.4 \\
& 2014 & 18.9 & 6.5 & 14.3 & 5.5 & 17.5 & 6.4 & 16.6 & 7.4 \\
& 2015 & 21.4 & 5.4 & 14.6 & 4.1 & 16.3 & 6.0 & 18.2 & 6.7 \\
Yerbas Buenas & 2014 & 17.6 & 5.2 & 13.1 & 3.9 & 18.5 & 6.3 & 19.2 & 8.0 \\
Chimbarongo & 2015 & 18.9 & 5.1 & 12.8 & 4.4 & 15.9 & 6.1 & 17.1 & 8.7 \\
Los Niches & 2013 & 17.5 & 5.6 & 13.4 & 4.6 & 17.2 & 10.3 & 19.0 & 9.3 \\
& 2014 & 18.6 & 4.2 & 12.6 & 3.4 & 18.6 & 1.7 & 24.7 & 6.1 \\
Peor es nada & 2012 & 20.5 & 6.5 & 12.3 & 4.0 & 17.5 & 6.4 & 19.7 & 7.4 \\
Angol & 2012 & 17.2 & 5.9 & 12.1 & 3.9 & 16.6 & 5.3 & 17.2 & 5.2 \\
& 2013 & 17.5 & 6.2 & 12.0 & 3.7 & 14.9 & 3.2 & 21.1 & 3.7 \\
& 2014 & 17.0 & 7.0 & 12.8 & 5.4 & 16.8 & 5.8 & 16.4 & 6.6 \\
& 2015 & 18.4 & 7.6 & 13.0 & 4.9 & 16.0 & 6.1 & 17.4 & 6.6 \\
\hline
\end{tabular}




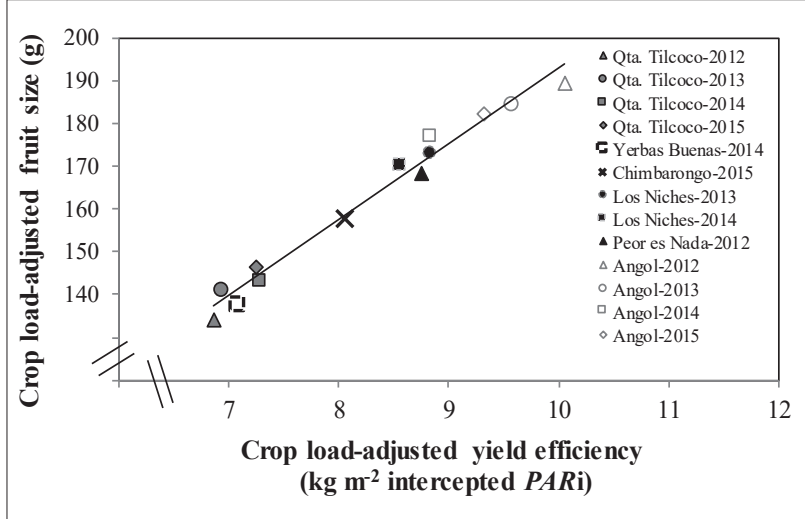

FIGURE 2. Relationship between fruit weight $(\mathrm{g})$ and yield efficiency $\left(\mathrm{kg} \mathrm{m}^{-2}\right.$ of intercepted $\left.P A R\right)$, both adjusted by crop load (fruit $\mathrm{m}^{-2}$ of intercepted $P A R$ ) for all cases (location/ season).

difference in productivity when comparing the extreme cases. By adjusting the productivity and size of the fruit by the fruit load variable, the effect of this variable on the yield is eliminated, therefore, the yield clearly depends on the size of the fruit. In general terms, the extremes detected in the yield efficiency and the fruit size corresponded to those locations with extreme latitudes: $34^{\circ} 20^{\prime} \mathrm{S}$ (Quinta de Tilcoco) and $37^{\circ} 40^{\prime} \mathrm{S}$ (Angol). These two orchards are roughly $400 \mathrm{~km}$ apart from one another in central Chile.

Exploratory data analysis performed using PCA explained close to $57.5 \%$ of the variability with the first two components (Figure 3). The first component (38.5\%) was associated with fruit weight and yield efficiency being opposed to maximum temperature during winter, autumn, and early budbreak ( $\mathrm{T}_{\text {Max }}$ Sep 1).

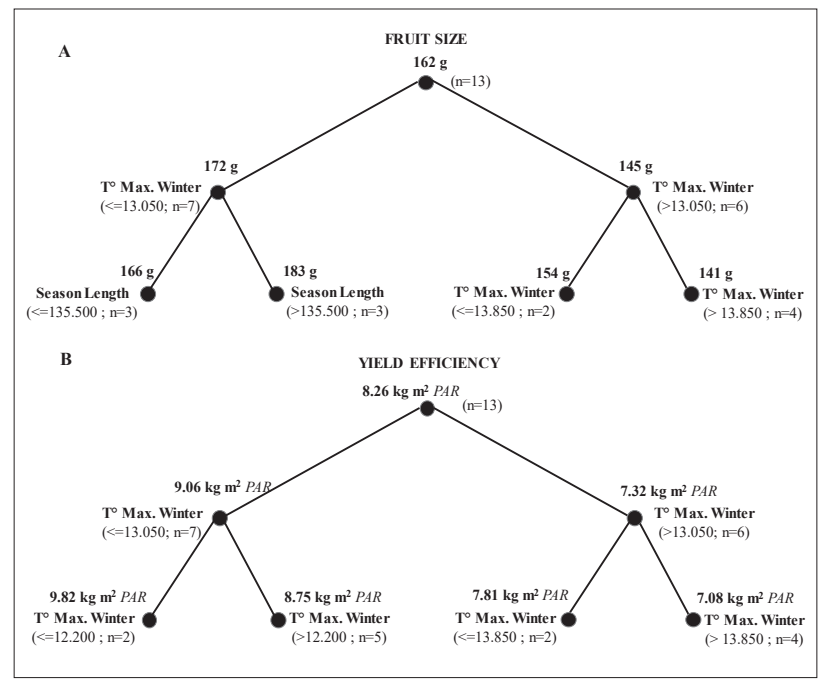

FIGURE 4. Regression trees for crop load-adjusted fruit size (A) and crop load-adjusted yield efficiency (B) as related to the maximum average temperatures during winter and season length.

The multiple regression analysis selected models with a high coefficient of determination (over 90\%), and included a linear response to the maximum temperature during the winter months and a curvilinear response to the season length (Table 3), where the crop load-adjusted fruit size increases as the season length increases from 120 to 140 days.

When the regression trees for fruit size and yield efficiency adjusted by crop load were built (Figure 4), a tree that included the maximum average temperatures during the winter season and the season length could explain the fruit size at harvest. For this variable, separation occurred at $13.05^{\circ} \mathrm{C}$, which split the cases into two groups: big fruit size, and small fruit size. The small fruit size group was also separated into two further groups at $13.85^{\circ} \mathrm{C}$ : upper small, and lower small, which means that the higher the maximum

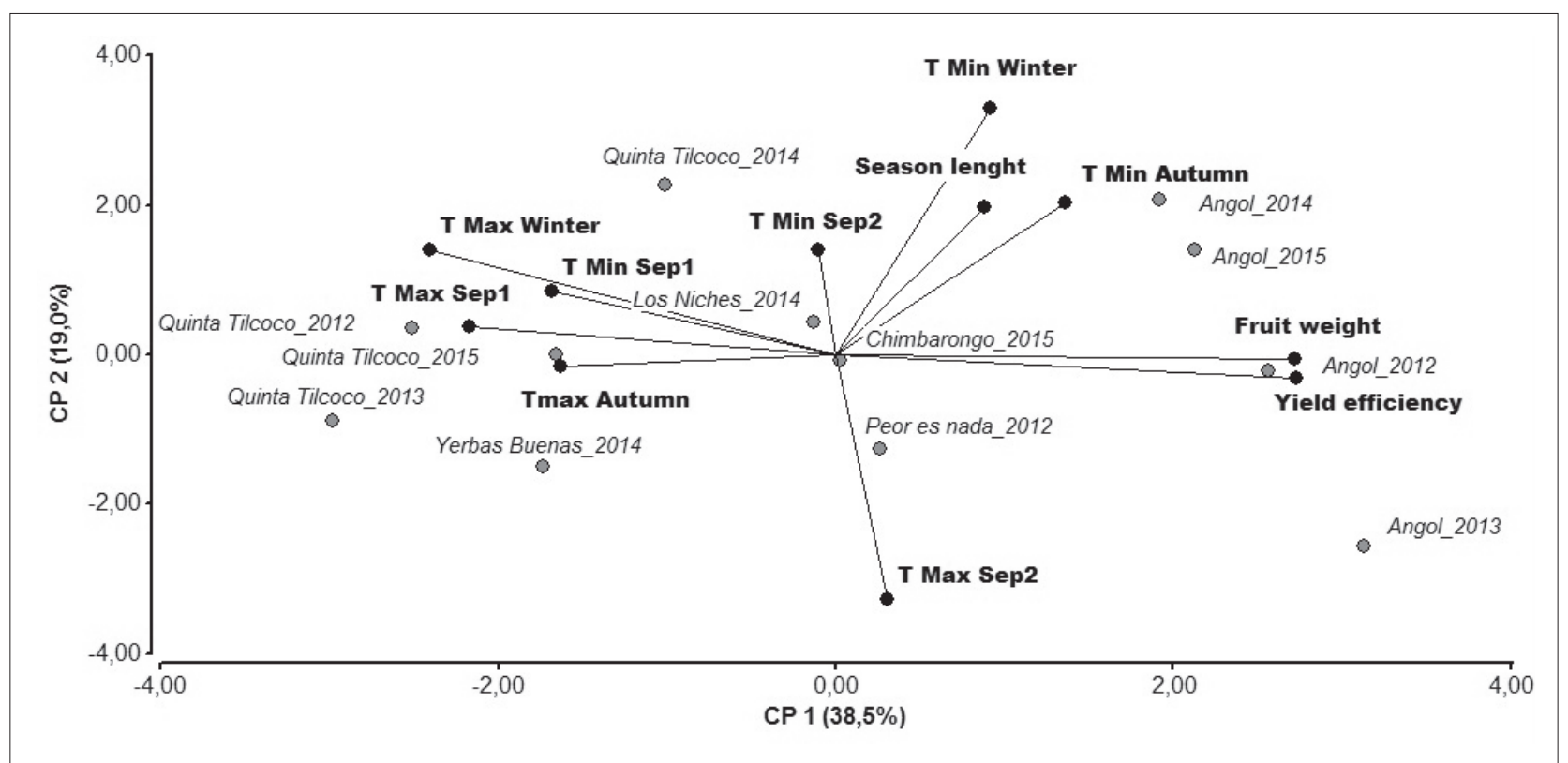

FIGURE 3. Principal component analysis for different cases (location/season) under review. The gray dots and italics indicate the cases. The black dots and the rays' length indicate the variability of the maximum and minimum temperatures during autumn, winter, and early (Sep1) or late (Sep2) pre-bloom and season length. 
TABLE 3. Selected models that explain crop load-adjusted fruit size and yield efficiency.

\begin{tabular}{lcc}
\hline Variable & Model & $\mathrm{R}^{2}$ \\
\hline Crop load-adjusted fruit size & $-1490.48-18.56^{*} \mathrm{~T} \mathrm{M} \times \mathrm{W}+27^{*} \mathrm{SL}-0.095696^{*} \mathrm{SL}^{2}$ & $91 \%$ \\
Crop load-adjusted yield efficiency & $-54.03-1.08^{*} \mathrm{~T} \mathrm{M} \mathrm{M} \mathrm{W}+1.07^{*} \mathrm{SL}-3.73 \mathrm{E}-03^{*} \mathrm{SL}^{2}$ & $93 \%$ \\
\hline
\end{tabular}

$\mathrm{T} \mathrm{M} \times \mathrm{W}=$ average of maximum temperature during winter (June-July-August); $\mathrm{SL}=$ Season length.

temperature during the winter months, the smaller the fruit size will be. The big fruit size group was separated into two groups according to season length: over 135.5 days, and under 135.5 days; for a longer season, the fruit will be bigger in size (Figure 4). Thus, for maximum fruit size potential, the maximum temperature during the winter should be low while the growing season should be long, as this normally corresponds to milder temperatures shortly after bloom (Warrington et al., 1999; López and DeJong, 2008).

The regression tree for the crop load-adjusted yield efficiency was explained only by the average of the maximum temperatures during the winter months (Figure 4). The groups with lower yield efficiency were separated at the same temperatures, dividing the cases based on fruit size. However, the group with higher yield efficiency was also separated by maximum temperatures during the winter months, reaching the threshold of the top high yield at $12.2^{\circ} \mathrm{C}$. Thus, the higher the maximum temperature during the winter months, the lower the yield efficiency will be.

\section{Discussion}

According to Warrington et al. (1999), the crop load and the genetic carrying capacity (i.e., the source-sink relationship) determine the potential for apple fruit size development. In each experimental case (location/season), there was a small variation in fruit size, even though a wide range of crop load was used, from 30 to 80 fruit $\mathrm{m}^{-2} P A R_{\mathrm{i}}$. This means a fully developed orchard (75\% PAR interception) would yield between 225,000 and 600,000 fruit ha- ${ }^{-1}$. Considering all the cases, the general trend showed that a $15 \%$ reduction in fruit size resulted in a change in yield efficiency by $120 \%$, thus indicating that in this cultivar, a negligible impact on fruit size could be seen when a narrow range of crop load is used (as is usual when crop load is regulated in well-managed orchards). This result also indicates that in all the cases under investigation, the source-sink relationship was not the main limiting factor to obtain well-sized fruits. Here, it should be pointed out that crop load was expressed in terms of PAR intercepted by the trees in order to consider that orchard yield is a direct function of PAR interception (Wünsche et al.,1996) and crop load (Reginato et al., 2007).

Agreeing with Lakso et al. (1999), an imbalance of carbon between source and sink can affect heavy crop-loaded trees either early or late in the season. During the early season, the developing leaves and the growing fruit are competing sinks because there is a source limitation due to insufficient leaf area development (Mehouachi et al., 1995). Later in the season, because the sink is greater, the leaf area might be limited or less active. Hansen (1971) reported that apple flowers depend on reserves only during their earliest stages of development; after this, photosynthesis becomes the primary source of carbohydrates for the flower and subsequent fruit growth. Thus, for these trials, it could be argued that trees with the heavy crop loads could have affected fruit size, as higher crop loads were imposed from the early developmental stages after bloom. In fact, all the trees, including the control trees, were left with all fruit remaining after chemi- cal treatments for nearly 50 days. Then, the trees were handthinned to the crop load range discussed above. The lack of differences in the crop load-adjusted fruit size among the thinning treatments (data not shown), and between them and control treatment, tell us that the competition among the fruit during the earlier developmental stages were not the main reason for the final fruit size.

The length of the period between bloom and commercial harvest is also related to the source-sink relationship; differences in this relationship were nullified when the crop load, expressed in terms of $P A R$, was considered as a covariant to calculate crop load-adjusted fruit size. The extension of season length, ranging from 120 to 140 days, positively affected the size of the fruit. With respect to this, López and DeJong (2008) found that warmer conditions - expressed as growing degree hours for 30 days after bloom $\left(\mathrm{GDH}_{30}\right)$ - during the early phase of stone fruit growth showed a reduced time period from bloom to harvest, along with reduced fruit size. This effect was attributed to a higher demand of assimilates in a shorter period of time. As discussed above, in the current investigation, the competition among the fruit during early developmental stages would not have been the driving factor of fruit size, but this could have had an effect later. Another factor that would support this hypothesis is that the effect of season length was detected when the potential fruit size was not limited by the effect of the higher temperatures during winter (the lower winter temperature group and the greater fruit size), separating the upper big fruit size group. The greater demand of assimilates of this size group could be sustained for the same amount of leaf area (the fruit size was adjusted for crop load by $P A R$ interception), but for a longer period of time. This longer season would result from less heat accumulation after bloom (López and DeJong, 2008).

Two additional facts support the idea that fruit size was previously determined, stemming from conditions that occurred before bloom. First, Reginato et al. (2015) detected that actual apple growth during the 25 days following bloom (measured in the field) was slowed down in a low fruit size producer area (i.e., Quinta de Tilcoco, Chile) when contrasted with a big fruit size location (i.e., Angol, Chile), even though the predicted growth using the Malusim model was similar (Lakso et al., 2001) among the locations, showing the weather similarity among them during the early fruit growth period. Second, although generally not significant, in all of the experiments, fruit size increased when benzyladenine was added to the thinning treatments (Reginato et al., 2015); this probably led to an increase in the number of cells by stimulation of cell division, thus increasing the sink strength (Wismer et al., 1995).

Although the effect of winter temperatures on the potential fruit size of 'Gala' cultivars has been suspected, when comparing the different apple-producing areas around the world, this effect has not been documented. With respect to this, Francescatto (2014) found less-developed buds in milder areas, such as in Vacaría, Brazil, in contrast to a colder area, such as Ohio, USA. Thus, smaller buds could lead to smaller sized apples, especially in cultivars that are genet- 
ically size-limited, such as 'Gala'. In this case, the limitation would be imposed mainly by winter climatic conditions, associated with higher temperatures.

As a conclusion, the results of this investigation showed that the fruit size of 'Gala' apples grown in central Chile was associated to environmental factors after removing the effect of thinning practices. We found that the maximum average temperature during the winter months (from June to early pre-bloom) is the key element in determining the potential fruit size in a particular location. In summary, the lower the maximum temperatures during winter months, the greater the potential for fruit size and yield. This result acquires significant importance when considering the increasing global temperatures due to the phenomenon of climate change.

\section{References}

Abbott, D.L. (1971). Physiology of fruit-set in apple. Effect of spring temperature. Ann. Rep. Long Ashton Res. Stn. 1970, 30-31.

Beattie, B.B., and Folley, R.R.W. (1977). Production variability in apple crops. Sci. Hort. 6, 271-279. https://doi.org/10.1016/03044238(77)90084-X.

Francescatto, P. (2014). Desenvolvimento das estruturas reprodutivas da macieira (Malus domestica Borkh.). Sob diferentes condições climáticas - da formação das gemas à colheita dos frutos. Ph.D. thesis (Florianópolis, Brazil: Universidade Federal de Santa Catarina).

Hansen, P. (1971). ${ }^{14} \mathrm{C}$-Studies on apple trees. VII. The early seasonal growth in leaves, flowers and shoots as dependent upon current photosynthates and existing reserves. Physiol. Plant 25(3), 469-473. https://doi.org/10.1111/j.1399-3054.1971.tb01475.x.

Jackson, J.E., and Hamer, P.J.C. (1980). The causes of year-to-year variation in the average yield of Cox's Orange Pippin apple in England. J. Hort. Sci. 55, 149-156. https://doi.org/10.1080/00221 589.1980.11514917.

Jackson, J.E., Hamer, P.J.C., and Wickenden, M.F. (1983). Effects of early spring temperatures on the set of fruits of Cox's Orange Pippin apple and year-to-year variation in its yields. Acta Hortic. 139, 7582. https://doi.org/10.17660/ActaHortic.1983.139.10.

Lakso, A.N., Corelli Grappadelli, L., Barnard, J., and Goffinet, M.C. (1995). An expolinear model of the growth pattern of the apple fruit. J. Hort. Sci. 70, 389-394. https://doi.org/10.1080/14620316.1995. 11515308.

Lakso, A.N., Wünsche, J., Palmer, J.W., and Corelli Grappadelli, L. (1999). Measurement and modeling of carbon balance of the apple tree. HortScience 34, 1040-1047. https://doi.org/10.21273/ HORTSCI.34.6.1040.

Lakso, A.N., White, M.D., and Tustin, D.S. (2001). Simulation modeling of the effects of short and long-term climatic variations on carbon balance of apple trees. Acta Hortic. 557, 473-480. https:// doi.org/10.17660/ActaHortic.2001.557.63.

López, G., and DeJong, T. (2008). Using growing degree hours accumulated thirty days after bloom to help growers predict difficult fruit sizing years. Acta Hortic. 803, 175-180. https://doi. org/10.17660/ActaHortic.2008.803.22.

Mehouachi, J., Serna, D., Zaragoza, S., Agusti, M., Talon, M., and PrimoMillo, E. (1995). Defoliation increases fruit abscission and reduces carbohydrates levels in developing fruits and woody tissues of Citrus unshiu. Plant Sci. 107, 189-197. https://doi.org/10.1016/01689452(95)04111-7.

Oliveira, C.M., and Priestley, C.A. (1988). Carbohydrate reserves in deciduous fruit trees. Hort. Rev. 10, 403-430. https://doi. org/10.1002/9781118060834.ch10.
Reginato, G., Riquelme, C., and Robinson, T.L. (2015). Raleo químico del manzano en Chile. Apple chemical thinning in Chile. Serie Ciencias Agronómicas No. 24 (Santiago, Chile: Universidad de Chile).

Reginato, G.H., García de Cortázar, V.G., Robinson, T.L., and Varela, J. (2007). Crop load expressed in terms of intercepted photosynthetically active radiation can be used as a covariate to compare peach tree performance. J. Hortic. Sci. Biotechnol. 82(5), 715-720. https://doi.org/10.1080/14620316.2007.11512295.

Rodrigo, J., and Herrero, M. (2002). Effects of pre-blossom temperatures on flower development and fruit set in Apricot. Sci. Hortic. 92(2), 125-135. https://doi.org/10.1016/S03044238(01)00289-8.

Warrington, I.J., Fulton, T.A., Halligan, E.A., and De Silva, H.N. (1999). Apple fruit growth and maturity are affected by early season temperatures. J. Am. Soc. Hort. Sci. 124(5), 468-477. https://doi. org/10.21273/JASHS.124.5.468.

Wismer, P.T., Proctor, J.T.A., and Elfving, D.C. (1995). Benzyladenine affects cell division and cell size during apple fruit thinning. J. Amer. Soc. Hort. Sci. 120(5), 802-807. https://doi.org/10.21273/ JASHS.120.5.802.

Wünsche, J.N., Lakso, A.N., Robinson, T.L., Lenz, F., and Denning, S.S. (1996). The bases of productivity in apple production systems: the role of light interception by different shoot types. J. Am. Soc. Hort. Sci. 121, 886-893. https://doi.org/10.21273/JASHS.121.5.886.

Received: Sep. 17, 2017

Accepted: Mar. 6, 2018

Addresses of authors:

Gabino Reginato ${ }^{1, *}$, Karen Mesa ${ }^{2}$ and Cristián Riquelme ${ }^{1}$

${ }^{1}$ University of Chile, Faculty of Agricultural Sciences,

Santiago, Chile

2 Instituto de Ciencias Agronómicas y Veterinarias,

Universidad de O'Higgins, Rancagua, Chile

* Corresponding author; E-mail: greginat@uchile.cl

Tel.: +56229785727; Fax: +56229785813 
Supplementary TABle 1. Average mean temperatures during autumn, winter, and early and late pre-bloom for different cases under study (location and season).

\begin{tabular}{lccccc}
\hline \multirow{2}{*}{ Location } & Year & \multicolumn{3}{c}{ Mean temperature $\left({ }^{\circ} \mathrm{C}\right)$} \\
\cline { 3 - 5 } & & Autumn & Winter & Early pre-bloom & Late pre-bloom \\
\hline Quinta de Tilcoco & 2012 & 13.5 & 9.0 & 13.1 & 12.1 \\
& 2013 & 12.0 & 9.0 & 9.9 & 9.9 \\
& 2014 & 12.7 & 9.9 & 12.0 & 12.0 \\
Yerbas Buenas & 2015 & 13.4 & 8.4 & 11.2 & 12.5 \\
Chimbarongo & 2014 & 11.4 & 8.5 & 12.4 & 13.6 \\
Los Niches & 2015 & 12.0 & 9.0 & 11.0 & 12.9 \\
& 2013 & 11.6 & 8.0 & 13.8 & 14.2 \\
Peor es nada & 2014 & 11.4 & 8.2 & 10.2 & 15.4 \\
Angol & 2012 & 13.5 & 8.0 & 11.0 & 13.6 \\
& 2012 & 11.6 & 7.9 & 9.1 & 11.2 \\
& 2013 & 11.9 & 9.1 & 11.3 & 12.4 \\
\hline
\end{tabular}

Supplementary TABle 2. Average of the values of fruit size (g), yield efficiency $\left(\mathrm{kg} \mathrm{m}^{-2} \mathrm{PAR}_{\mathrm{i}}\right)$ and season length evaluated during among the years of the experiment on each orchard (location/season). Calculated the crop load adjusted for fruit size and yield efficiency.

\begin{tabular}{|c|c|c|c|c|c|c|}
\hline \multirow[t]{2}{*}{ Location } & \multirow[t]{2}{*}{ Year } & Fruit size & $\begin{array}{l}\text { Crop load adjusted } \\
\text { fruit size }\end{array}$ & $\begin{array}{c}\text { Yield } \\
\text { efficiency }\end{array}$ & $\begin{array}{c}\text { Crop load adjusted } \\
\text { yield efficiency }\end{array}$ & \multirow{2}{*}{$\begin{array}{c}\text { Season } \\
\text { length } \\
\text { Days }\end{array}$} \\
\hline & & \multicolumn{2}{|c|}{ - } & \multicolumn{2}{|c|}{-- $\left(\mathrm{kg} \mathrm{m}^{-2} \mathrm{PAR}_{\mathrm{i}}\right)^{-}$} & \\
\hline \multirow[t]{3}{*}{ Quinta de Tilcoco } & 2012 & 134.42 & 141.30 & 6.86 & 6.91 & 146 \\
\hline & 2013 & 141.07 & 140.05 & 6.94 & 6.52 & 134 \\
\hline & 2014 & 143.49 & 142.38 & 7.27 & 6.90 & 139 \\
\hline Yerbas Buenas & 2014 & 137.92 & 143.43 & 7.07 & 6.92 & 122 \\
\hline \multirow[t]{2}{*}{ Los Niches } & 2013 & 173.27 & 174.89 & 8.82 & 8.43 & 131 \\
\hline & 2014 & 170.30 & 173.78 & 8.55 & 8.20 & 138 \\
\hline Peor es nada & 2012 & 168.52 & 172.81 & 8.75 & 8.26 & 128 \\
\hline \multirow[t]{3}{*}{ Angol } & 2012 & 189.51 & 185.04 & 10.05 & 9.55 & 146 \\
\hline & 2013 & 184.37 & 184.25 & 9.58 & 9.21 & 139 \\
\hline & 2014 & 177.35 & 178.34 & 8.83 & 8.44 & 143 \\
\hline
\end{tabular}

